\title{
Moleküler Gastronomi Bilimsel Bir Disiplin, NbN Mutfak Bir Sonraki Mutfak Eğilimidir ${ }^{1}$
}

\author{
Molecular Gastronomy is a Scientific Discipline, and Note by Note Cuisine is The Next Culinary Trend
}

\section{Herve THIS*}

* Académie d'Agriculture de France

Türkçeye çevirenler:

\author{
Şehnaz DEMiRKOL**, İbrahim ÇiFÇi*** \\ **Yardımcı Doçent Doktor, İstanbul Üniversitesi, İktisat Fakültesi, 34116, Fatih, İstanbul. \\ E-posta: sdemirkol@istanbul.edu.tr \\ ***Araştırma Görevlisi, İstanbul Üniversitesi, İktisat Fakültesi, 34116, Fatih, İstanbul. \\ E-posta: ibrahim.cifci@istanbul.edu.tr
}

MAKALE BILGILERI

Anahtar sözcükler: Mutfak, Moleküler mutfak, Moleküler gastronomi, NbN mutfak.

\section{ARTICLE INFO}

Key words: Cuisine, Molecular cuisine, Molecular gastronomy, Note by note cuisine.

\begin{abstract}
Son yirmi yılda, moleküler gastronomi konusunda çok fazla kavram karmașası yaşanmıştır. Bu karmaşıklık insanların gastronomi kelimesini mutfak ile eşdeğer kullanması ve gastronominin gııdalar hakkındaki bilgiler içeren bir disiplin olduğunu görmezden gelmesinden kaynaklanmıştır. 'Moleküler Biyoloji' ile benzer bir şekilde Moleküler Gastronomi, yiyeceklerin hazırlanması ve tüketimi esnasında meydana gelen olguları araștıran bilimsel bir disiplindir. Dolayısıyla, diğer bilimsel disiplinlerde olduğu gibi, birçok uygulamayı da beraberinde getirmektedir. Bu alandaki uygulamaların ilki moleküler mutfak uygulaması, zamanla dönüşüm geçirmiş 1994 yılından bu yana 'NbN Mutfağı' olarak gelişimine devam etmiştir. İkincisi, yiyeceklerin kendilerini kullanmak yerine bitki ve hayvan dokularını ayrıștırılarak elde edilen saf bileșikleri kullanarak yiyeceklerin hazırlamasına dayanmaktadır. NbN mutfak, bilim, teknoloji, beslenme, fizyoloji, toksikoloji ve politika olmak üzere çeşitli alanlarla da ilgilidir.
\end{abstract}

\section{ABSTRACT}

For the past two decades, there has been much confusion about molecular gastronomy. This confusion has arisen because people ignore that the word gastronomy does not mean cuisine, it means knowledge about food. Similar to 'molecular biology', molecular gastronomy is a scientific discipline that looks for the mechanisms of phenomena occurring during dish preparation and consumption. As with any other scientific discipline, it can have many applications. One of the first was 'molecular cuisine' but since 1994, 'note by note cuisine' has also been promoted. The latter involves preparing dishes using pure compounds, or more practically mixture of compounds obtained by fractioning plant or animal tissues, instead of using these tissues themselves. Note by note cuisine raises issues in various fields: science, technology, nutrition, physiology, toxicology and politics.

\section{MOLEKÜLER GASTRONOMI}

Moleküller Gastronomi (MG), 1988'de yeni bir bilimsel disiplin olarak , 'yiyeceklerin hazırlanması ve tüketimi esnasında oluşan olguların araştıran bilim dalı' şeklinde tanımlanmıştır (This 1995; 2003). Bu yeni tanım, moleküler gastronominin

\footnotetext{
${ }^{1} \mathrm{Bu}$ yaz1, Hervé This (2013). Molecular gastronomy is a scientific discipline, and note by note cuisine is the next culinary trend, This Flavour, 2013, 2:(1): 1-8" künyesini taşıyan makaleden, izin alınarak çevrilmiştir.
}

içeriğinin ve diğer bilim dallarıyla olan ilişkisinin tartı̧̧ma konusu haline gelmesine neden olmuştur.

Gida konusunda bilim ve teknoloji arasında daima bir kavram kargaşası yaşanmıştır. Bu kavram karmaşası, gıdaların aslında tam olarak ne olduğunun tartışılmasına kadar varmaktadır. Sözlük anlamı olarak gidalar şu şekilde tanımlamaktadır: 'canlı varlıklara büyümeleri veya korunmaları için gerekli unsurları verebilen herhangi bir madde' (Trésor de la langue française 
2006). Bununla birlikte, insanlar nadiren dönüşüme uğramamış doğal ürünler yemektedir. Ham gıdalar genellikle bir dönüşüm geçirdikten sonra tüketici ile buluştukları için, bu dönüşün neticesinde gidada meydana gelen kimyasal ve fiziksel değişiklikler bütün yiyeceklerde olduğu gibi "biyoaktivite'de" de son yapıyı belirlemektedir. "Biyoaktivite'yi" ise duygusal etkiler, besin değeri, nihai toksik etkiler gibi besin sistemi tarafından ortaya çıkarılan çeşitli bileşikleri tanımlamaya yarayan bir terim olarak görebiliriz (This 2012).

Yiyecekler hazırlanırken, bitki veya hayvan dokuları en nihayetinde yıkanmakta, kesilmekte ve çoğu gıdalar ısıl işlemler kullanılarak hazırlanmaktadır. Örneğin, 1sısal bir işleme gerek duymayan basit bir havuç salatası için bile, tarladaki ham ürün ile tüketilen, yani bir tabakta rendelenmiş havuç arasında büyük bir fark bulunmaktadır: Çünkü dokuları kesmek enzimsel reaksiyonları tetiklemektedir (Zawistowski vd. 1991). Bu durum, havucu oluşturan bileşiklerin, yapının dış kısmı ve bitki dokusu arasında yer değiştirmesinden kaynaklanmaktadır (Cazor ve This 2006). Böylelikle, mutfakta dönüşüme uğramış ürünlerinin gıda olarak adlandırılmaması gerektiği söylenebilir. Hammaddeden nihai ürüne, yani yiyeceklerin oluşumuna kadarki dönüşüm süreci, hem bilimsel hem de teknolojik nedenlerden dolayı araştırmaya değer görülmektedir.

Kamuoyunun aşırı derecede 'yiyeceklerdeki kimyasal' dan korkması nedeniyle, MG açısından bilim ve pişirme arasındaki kavram karmaşasını gidererek bilim ve teknoloji arasındaki farkı netleştirmek özellikle önem arz etmektedir [Bkz. (Moleculargastronomynetwork 2013)], (bu durum aşağıda açıklandığı şekilde NbN (Note by Note) mutfağının gelişimi açısından önem arz etmektedir). Fransiz kimyager Antoine-Laurent de Lavoisier, et-suyu hakkındaki makalesinde (De Lavoisier AL 1862-1893), bilim ve teknoloji gibi iki alanının aynı olguyu ifade etmediğini belirtmektedir. Bilimsel ve teknoloji alanda çok başarılı olan Fransız kimyager ve biyolog Louis Pasteur, uygulamalı bilimler ifadesine şiddetle karşı çıkmıştır (Pasteur 1924). Dolayısı ile bilim ve gıda dönüştürme teknolojisi arasında önemli bir fark olduğunu söyleyebiliriz (This 2009). İkincisi, yemeğin hazırlanması ve tüketilmesi, yani moleküler gastronomi esnasında ortaya çıkan olgulara ilişkin bilimsel çalışmalar ile teknolojik uygulamalar birbirleri ile kıyaslanamayacak durumdadır. 'Mutfak Bilimi' veya 'Pişirme Bilimi' (This 2011) gibi cümlelerde kastedilen bu olguların genel anlamda mutfaktaki bilgi birikimini kast etmediği sürece kesinlikle yanlış olduğunu belirtmemiz gerekmektedir. Ayrıca, medyada sık sık karşılaşılan ifadelerin aksine 'bilimsel şefler' de doğru bir tanım değildir (Finedininglovers 2011). Elbette, moleküler gastronomi disiplinin geçmişte emsalleri olmuştur (This 1997) ve yiyeceklerin hazırlığı ve tüketimi esnasında ortaya ç1kan pek çok kimyasal veya fiziksel olgu 1988'den önce de incelenmiştir (Bkz. Cadet 1733). Ancak, 1980'li yıllara kadar gıda bilimi pişirme süreçleri ile ilgilenmemekteydi. Örneğin, klasik ders kitaplarından biri olan 'Gıda Kimyası' gıda dönüşümleri hakkında neredeyse hiçbir bilgi içermemektedir [Bu durum en son baskısında bile hala geçerli bir durumdur] (Belitz ve Grosch 1999), et ile ilgili önemli bölümlerin \% 0,5'inden az bir kısmında gıda dönüşümlerinden bahsedilmiştir (örneğin, et üzerinde $1 s ı l$ işlem uygulandığında çekme (küçülme) meydana gelmektedir); kitabın bölümlerinin çoğunda çiğ et bileşimi, yapısı veya sanayi ürünlerden (sosis, et özleri ve benzeri) bahsedilmiştir. Pişirilmiş şaraplar mutfaklarda yaygın olarak kullanılmasına rağmen (Fransız klasik soslarının\% 48'si şarap içermektedir; J Henne, MB Fransa, K Belkhir ve HT), aynı ders kitabı ısıl işlemin şaraplar üzerindeki etkisi hakkında hiçbir bilgi içermemektedir.

Pişirme esnasında meydana gelen dönüşümlerin karmaşıklığı ve gıda endüstrisinin kendi alanı dışındaki araştırmalar için genel finansman eksikliği yaşaması gibi konular nedeniyle gıda bilimi yavaşça katkı maddeleri ve gıda teknolojisi bilimine doğru yönelmiş ve bu nedenle de, cassoulet, gulaş, hollandaise gibi sosların pişirilme esnasında üzerlerinde meydana gelen fenomolojik olguların araştırması ihmal edilen bir konu olmuştur. Pişirme esnasındaki gıda dönüşümlerine gereken önemin verilmemesi nedeniyle, eski Oxford fizik profesörü Nicholas Kurti (19081998) ve ben Herve This, Mart 1988 tarihinde ye- 
ni bir disiplininin oluşturulması gerektiğine karar verdik (This 1995).

O yıllarda gida bilimlerindeki durum, daha önceki yıllarda moleküler biyolojinin içinde bulunduğu duruma benzerlik göstermekteydi. Moleküler biyoloji terimi ilk kez 1938'de Warren Weaver ve Rockefeller Vakfı tarafından finanse edilen programların anlatılması amacıyla kullanılmıştır. Basitçe yaşamsal süreçleri araştırmak amacıyla fiziksel bilimlerde geliştirilen tekniklerin uygulanması anlamına gelmekteydi (Baltimore 19331975). 1950'den önce bu terimi biyolojik moleküllerin yapıları, işlevleri ve oluşumlarının incelenmesi amaciyla kullanana William Astbury, 'moleküler biyoloji' olarak çalışmasını adlandıran ilk bilim adamdır (Weaver 1970). Kurti ile aklımda olan şey az ya da çok aynıydı, ancak başka bir bilim alanı olarak moleküler ve fiziksel gastronomi adı uygun görülmüştür. "Haute cuisine"den ziyade 'insanoğlunun beslenmesi ile ilgili tüm akıllı bilgi' anlamina gelen 'gastronomi' kelimesinin başlıkta kullanılmasının nedeni son derece açıktır (Savarin 2006). Kurti'nin 1998'deki ölümünün ardından, disiplinin adı moleküler gastronomi olarak kısaltılmıştır ve Kurti'nin ismi disiplinin uluslararası toplantılarına atfedilmiştir.

Yeni ortaya çıkan bu alanın çekici olması ve bilimsel açıdan keşfe açık olması dikkat çekmektedir; yeni bir olgu keşfedilmek istendiğinde, bu yeni alanın keşfi oldukça kazançlı bir bahis olarak görülebilir, çünkü bu alan yeni olması nedeniyle oldukça keşfe açık olacaktır. Yeni bilgiler üretildiğinde, teknolojik uygulamalar yapmak mümkün hale gelmektedir. 2000 yılından bu yana, moleküler gastronomiye dayalı yenilikler neredeyse her ay tanitılarak takdim edilmiştir (sıklıkla geçmişteki ünlü kimyagerlerin isimleri yeni çeşit yemeklere verilmiştir) (Pierre-Gagnaire 2012). Ancak, bu disiplinin başlangıç programı bilim ve teknolojiyi birbirine karıștırmasından dolayı pek uygun görülmemektedir. 2000 yılında herhangi bir tarifin "teknik olarak yararsız bir bölüm", bir "tanım" ve "teknik ek bilgi" şeklinde üç bölümden oluştuğu anlaşılmıştır (This 1998). Bu bölümlerle ilgili olan son terim, yiyeceklerin hazırlanması için kesinlikle gerekli olmayan bilgileri (eski kocakarı hikâyelerini, atasözleri- ni, ipuçlarını, bazı yöntemleri vb.) içermektedir (This 2010). Bundan birkaç yıl sonra bir yemeğin, insanlar tarafından değerlendirilirken tekniksel değil de sanatsal unsurlarının da göz önünde bulundurulduğunun farkına varılmıştır; $\mathrm{Bu}$ nedenle pişirmenin temel önem taşıyan sanatsal bir faaliyeti içerdiğini söyleyebiliriz. Pişirme ile ilgili aynı zamanda toplumsal bağlamın da çok önemli bir olgu olduğu anlaşılmıştır: Örneğin; bir yemeğin konukların yüzüne fırlatılması iyi bir durumu ifade etmemektedir. Bütün bu olgular, moleküler gastronomi için yeni bir program önerisine imkân tanımıştır:

1. 'Mutfak tanımlarını' bilimsel olarak keşfetmek;

2. Teknik ek bilgiler toplamak ve test etmek;

3. Pişirmenin sanat yönünü bilimsel olarak keşfetmek;

4. Pişirmenin sosyal yönünü bilimsel olarak keşfetmek (This 2004).

\section{MUTFAKTAKI UYGULAMALARI}

Moleküler gastronominin tanıtıldığı ilk yıllarda, ben ve diğer bilim adamları kimya, fizik ve biyoloji gibi bilim dallarında kullanılan yöntemleri kullanarak mutfak uygulamalarını modernleştirmeye çalıştık (This 1994). Teknikleri modernize etme anlayışı, mutfak tarihinde birçok kez gündeme gelmiş bir konudur. Kurti 1969'da fiziksel tekniklerin kullanımından bahsetmiştir (Kurti 1969). Bense, 1980 'lerin başından beri kimyasal araçların kullanımını önermekteyim (This 1995). Moleküler mutfak (veya moleküler pişirme) adı 1999'da, INICON adında bir FP5 Avrupa programının başında verilmiştir. Moleküler Mutfak, 'yeni araçlar, malzemeler, yöntemler kullanarak yiyecek üretmek' şeklinde tanımlanabilir (Horizon-2020 2003).

Bu tanımda, 'yeni' kelimesi, 1980'de batı ülkelerinin mutfaklarında bulunmayan unsurları ifade etmektedir. Yeni araçlar, köpük oluşturmak için kullanılan sifonları; emülsiyon yapmak için kullanılan ultrasonik sondaları; $100^{\circ} \mathrm{C}^{\prime}$ den daha düşük sıcaklıklarda pişirme uygulamaları yapabilmek için kullanılan kontrollü isitıcılar veya sirkülatörleri; sıvı azot ile şerbetler yapmak ve daha pek çok yenilikçi hazırlık yapmayı; ekstraktları 
iyileştirmek için kullanılan döner buharlaştırıcılar ve distilatörleri ve mutfaktaki yararlı uygulamalara sahip olabilecek diğer birçok laboratuvar ekipmanlarını içermektedir. Bileşenlerle ilgili olarak, 80'li yıllarda batı mutfaklarında kullanılmayan, ancak yararlı mutfak uygulamalarına sahip oldukları kanıtlanan sıvı içerikleri jelleştiren sodyum aljinat, agar-agar veya karegenan; çeşitli renklerdeki koku bileşikleri vb. tüm bu ürünler tam anlamıyla yeni değildir. Örneğin, jelleştirmede kullanılan ve çeşitli tatlı su yosunlardan üretilmiş jelleme ürünleri Asya'da binlerce yıldır kullanılmaktadır. Ayrıca, moleküler mutfakta kullanılan laboratuvar malzemeleri de yeni araçlar değildir. Ancak, bu zamana kadar batılı şefler tarafından teknik malzemeleri kullanarak mutfak uygulamalarını modernize etmek için kullanılmamıştır.

Yeni yöntemler açısından, çikolata chantilly, beaumés, gibbs, nollet, liebig, gay-lussac, braconnot veya vauquelins gibi bir dizi yenilikçi hazırlıkla oluşturulan (genellikle tarihteki bilim insanlarının isimlerinin verilmesiyle adland1rılmış) yiyecekler tanıtılmıştır (Pierre-Gagnaire 2012). Moleküler mutfak teriminin eleştirildiği zamanlar olmuştur, ancak moleküler mutfağın kullanılmasındaki esas amaç yenilikçi mutfak uygulamaları ile bilim ve özellikle moleküler gastronomi arasındaki farkın ayırt edilmesinin gerekliliğidir. Moleküler mutfak teriminin yeni teknikler benimsenerek yok olma ihtimalinin bulunması nedeniyle isimler üzerindeki argümanlar pek önem arz etmemektedir. Örneğin şimdilerde bu tarz mutfak uygulamaları yeni bir fikir olan $\mathrm{NbN}$ mutfak ismiyle tanıtılmaya başlamıştır (This 1999).

\section{BIR SONRAKI MUTFAK EĞiLIMI: NbN MUTFAK!}

NbN mutfak ilk kez 1994 yılında [Scientific American dergisinde (This ve Kurti 1994) 25)] içecek ve yiyeceklerde şaraplar ve viskilerin içeriğindeki gibi paraetilfenol bileşikler kullanmaya başladığımda gündeme gelmiştir. Örnek olarak Et soslar1 1-okten-3-ol; limonen; tartarik asit ve askorbik asit içermektedir. $\mathrm{NbN}$ mutfağının ilk önerisi yiyeceklerin geliştirilmesi ile ilgiliyken, bir sonraki adımı yiyeceklerin tamamıyla bileşiklerden yapılması fikrine dayanmaktadır.

Farklı bir şekilde ifade etmek gerekirse, $\mathrm{NbN}$ mutfak yiyecekleri hazırlamak için et, balık, sebze veya meyveleri kullanmak yerine saf bileşikler veya karışımlar içeren bileşikleri kullanmaktadır. Elektronik müzik bu konuya bir benzetme olabilir. Elektronik müzikte trampet veya keman gibi müzik aletlerinin kullanılmasının yerine, salt ses dalgalarının birbirlerine karıştırılarak ses ve müziğin meydana getirilmesi söz konusudur. $\mathrm{NbN}$ mutfağındaki yiyeceklerin çeşitli aşamalarında aşçının yiyeceklerin şekillerini, renklerini, bazı zevkleri, koku maddelerini, sıcaklıkları, trigeminal uyarımı, dokuları, besin öğelerini ve daha fazlasını tasarlaması gerekmektedir (L'Hotellerie-Restauration 2009). Bu yeni mutfağın uygulanabilirliği, 24 Nisan 2009'da Fransiz şef Pierre Gagnaire (dünya çapında bir düzine kentte restoranlara sahiptir: Paris, Londra, Las Vegas, Tokyo, Dubai, Hong Kong ...), tarafından Hong Kong'daki uluslararası basın toplantısı için ilk NbN mutfak uygulamasıyla hazırlanan yiyeceklerin sunulması ile kanıtlanmıştır. Daha sonraları, Mayıs 2010'da Alsas şehrinden Hubert Maetz ve Aline Kuentz ismindeki aşçılar tarafından Strazburg'daki Fransız-Japon Bilimsel Toplantısı'nda NbN mutfakta hazırlanmış iki yemek çeşidi katılımcilara sunulmuştur (Canalc2tv 2010). Buna rağmen, Ekim 2010 tarihine kadar $\mathrm{NbN}$ mutfak uygulaması ile hazırlanan yiyecekler Paris'teki Cordon Bleu Okulu şefleri tarafından Gastronomide İleri Araştırmalar Enstitüsü'ndeki kurs programlarının katılımcılarına sunulmamıştır (Cordonbleu 2011). 26 Ocak 2011'de, Paris'te düzenlenen Birleşmiş Milletler Eğitim, Bilim ve Kültür Örgütü Uluslararası Kimya Yılı etkinliğinin başlatılmasından önce düzenlenen bir ziyafette Potel et Chabot Catering Şirketi tarafından yaklaşık 150 kişiye $\mathrm{NbN}$ mutfak uygulaması ile hazırlanmış yiyecekler servis edilmiştir (Hotellerie-Restauration 2011). Aynı yiyecekler yine, Nisan 2011'de Paris'teki Michelin yıldızına sahip yaklaşık 500 şefe de servis edilmiştir. $\mathrm{O}$ zamandan bu yana $\mathrm{NbN}$ mutfak ile ilgili girişimlerin sayısını takip etmek artık zorlaşmaya başlamiştır. 


\section{NbN MUTFAĞA iLIŞKIN KONULAR}

Birçok insan NbN mutfak uygulamaları hakkındaki endişelerine yönelik sorular sormaktadır. Besinler, oligo elemanları ve vitaminler bu mutfak uygulamasında ne durumdadır? Bileşikler tehlikeli midir? Yemekler sıvı formlar haline mi dönüşecekler? Bu yeni pişirme tekniği ile tarım uygulamaları son mu bulacak? Bu tarz her türlü argüman, geleneksel yiyeceklerin neden hala hayatımızda bulundurulması gerektiğini haklı çıkarmak için kullanılmaktadır. Aslında bu sorular önemli sorulardır ve $\mathrm{NbN}$ mutfak, ancak insanoğlunun 'g1da neofobisi' ile başa çıkabildiği takdirde başarılı olabilecektir (Pliner ve Hobden 1992): İnsan dışı diğer varlıkların da deneyimlediği bu refleks, bireyleri gençlik çağlarında "iyi" olarak nitelendirilip kendilerine öğretilen yiyecekleri kabul etmeye ve yeni yiyeceklerden korkmaya yönlendirmektedir. Ínsan beyni, insan dışı varlılarında yaptığı gibi yeni gıdaları reddetmemizi sağlamak yerine, yeni yemekleri reddetmek ve eski yemekleri meşrulaştırmaya bizleri yönlendirmektedir. Bu, geleneksel g1da maddelerinin 'erdemli' gösterilmediğinde bile yaşanmaktadir (EFSA Scientific Cooperation (ESCO) Report 2009). Bu konuyla ilgili en kötü gerekçe ise, bu besin türlerinin eski olduğu için güvenli olarak sayılmasıdır. Bu basit bir argümandır; geleneksel pişirme yönteminden olan tütsülenmiş ürünler göz önünde bulundurulduğunda, epidemiyologlar şimdilerde çok sayıda bu teknikle hazırlanan füme ürün tüketen kuzey Avrupa nüfuzunda sindirim sistemindeki kanserlerin görülme sıklığının yüksek olduğunu açıkça gözlemlemektedir.

Gıda neofobisi, $\mathrm{NbN}$ mutfağına olan ilgiyi azaltmak için iyi bir neden değildir. Neden geleneksel mutfağı bırakıp NbN mutfağını benimsemeliyiz? Bu durum gerçekten alternatif bir zorunluluk değildir; Moleküler mutfak anlayışında olduğu gibi, $\mathrm{NbN}$ mutfak anlayışını geleneksel mutfak anlayışı ile birleştirebiliriz. Ya da hybrid üretimler yapabiliriz...

\section{TEKNIK KONULAR}

$\mathrm{NbN}$ mutfak tekniği ile hali hazırda yiyecekler oluşturulmasından dolayı, $\mathrm{NbN}$ mutfağın uy- gulanabilirliği konusunda daha fazla tartışmaya gerek bulunmamaktadır, ancak bu mutfak anlayışı içerisinde kullanılan bileşiklerin yapısını tartışmak zorundayız. Mutfak dünyasında su, sodyum klorür, sakaroz ve jelatin gibi çok saf bileşikler zaten kullanılmaktadır. Gıda üretimiyle ilgili bilgisi olmayan bir kişi, bu bileşiklerin çeşitli ekstraksiyon işlemleri, saflaştırma ve teknolojik modifikasyonlar (örneğin, sakaroza eklenen agregasyon önleyici bileşikler) yoluyla endüstri tarafından hazırlandığı gerçeğini görmezden gelmektedir (Belitz ve Grosch 1999).

Sakkaritler, amino asitler ve gliseridler gibi diğer pek çok bileşik aynı şekilde hazırlanabilir. Aslında gıda endüstrisi hali hazırda zaten bunlardan bazılarını kullanmaktadır. Gıda katkı endüstrisi pigmentler, vitaminler, koruyucular, jelleşme ve koyulaştırma maddeleri vb. üretmektedir. Katkı maddeleri günümüzde g1da maddeleri gibi bir düzenlemeye tabi tutulmamıştır, ancak gelecekte neden düzenlenmesin ki? Veya katk1ların düzenlenmesi konusu görmezden gelinip, farklı birçok başka düzenlemeler mi getirilmelidir?

Saf bileşenlerden yemek yapmak zor bir işlemdir. Bu bağlamda müzik örneğimiz hatırlanacak olursa, yemek yapmanın bir alternatif yolunun da elektronik müzik yapmakla benzer olduğunu söylemiştik (Ircam 2010; Gelatin-Gmia 2013). Diğer bir deyişle, g1da endüstrinin hali hazırda süt ve tahıl ayrıştırması işleminde yaptı̆̆ı gibi, basit karışımlar eklenerek kullanılabilir bileşiklerin listesi genişletilebilir. Örneğin, jelatin, yalnızca tek bir tür molekülden oluşmaması nedeniyle saf bir bileşik değildir. Jelatin yapmak için kullanılan ekstraksiyon (özünü çıkarma) yöntemi, polipeptit zincirlerinin moleküler ağırlığında büyük farklılaşmaya neden olmaktadır (Lorient ve Linden 1994). Ayrıca nişasta da saf bir bileşik değildir, çünkü amilozlar ve amilopektinler olmak üzere iki ana bileşikten meydana gelmektedir. Nişasta tahılın basit bir kısmıdır. Burada bahsetmişken unutmayalım, çoğu geleneksel pasta tekniği NbN mutfak uygulamaları kullanılarak geliştirilebilir.

Ayrıştırılmış ürünler hazırlamak için bitki veya hayvan dokularının 'parçalanması' konusuna geri dönelim. Endüstri hali hazırda polisakkarit- 
ler, proteinler, amino asitler, yüzey aktif cisimleri ve tahıldan diğer bileşikleri ayrıştırmaktadır (Lorient ve Linden 1994). Endüstri sütten amino asitleri, peptidleri, proteinleri ve trigliseridleri elde etmektedir. Aynı şeyi bitkiden (havuç, elma, şalgam ...) veya hayvan dokularından yapamaz mıyız? Benzer tür işlemler ile (direkt veya ters osmoz, kriyokonsantrasyon veya vakum damitma gibi yöntemler) $\mathrm{NbN}$ mutfak için kullanılabilecek ayrıştırılmış ürünler hazırlayamaz mıyız? Birçok teknoloji grubu bu konular üzerinde çalışmaktadır. Örneğin, Montpellier Enstitüsü National de la Recherche Agronomique Merkezi Laboratuvarında, üzüm suyundaki toplam fenolik ayrıştırmayı geri kazanmak için mebran filtrelemesine dayanan teknikler geliştirilmiştir (Escudier 2010). Bu ayrıştırma işlemi hammaddeye bağlı olarak çok farklılık gösterebilmektedir: Örneğin, içeceğin özsuyu Syrah, Grenache veya Pinot çeşidinden olsa da, ilk ürünlerin çeşitliliği ayrıştırma işlemi ile yok olmamaktadır, böylece aşçlar 'teruar' ile oynayabilirler.

Bileşim maddeleri hakkında tartıştık, şimdi bunları yiyecekler ile birleştirmeyi düşünmeliyiz. Unutulmamalıdır ki günümüz gıda ürünleri genellikle içeriğinin büyük bir kısmın su barındırsa bile kolloidal bir yapıya sahip materyal sistemlerdir (This 2005; This 2007). Birçok organik bileşik suda az çözünmektedir. Bu nedenle, emülsiyonlaştırmanın $\mathrm{NbN}$ mutfak için çok önemli bir işlem olduğu söylenebilir. Ancak kullanılan tek işlem bu değildir; tüm ayrıştırma teknikleri $\mathrm{NbN}$ mutfakta kullanılabilecek faydalı yöntemlerdir.

Oluşturma esnasında, gıdaların çeşitli biyolojik özelliklerinin göz önünde bulundurulması gerekmektedir. Elbette, beslenme içeriği önem arz etmektedir, ancak gıdaların, görme, koklama, tatma, trigeminal sistem ve sicaklık gibi etkenler ile çeşitli duyu alıcılarını uyarmak zorunda olduğunu unutmak önemli bir hata olur (Roberfroid vd. 2007; This vd. 2012). Bu durum birçok merak edilen konuyu da beraberinde getirmektedir. Örneğin, bazı pigmentlerin birbirinden ayrı emilim renk yelpazesi bilinse bile (bazı pigmentlerin bireysel emilim spektrumu), bu pigmentlerin herhangi birinin karışımının renginin ne olacağını tahmin etmek teorik olarak zor bir işlemdir (This
2012). Ayrıca, koku bileşiklerini algılama eşiğine yakın oranlarda karıştırıldıklarında, öngörülemeyen kokular elde edilebilmektedir. Daha da ilginç olanı, sadece iki koku bileşiğini karıştırdığınızda neler olacağını bilmemekteyiz: bu bir 'akor' mu yoksa füzyon yani birleşme midir (Roberfroid vd. 2011)?

Tat algilama konusu bu durumdan daha karmaşık bir hale gelmektedir, çünkü tat algılayıc1ları ve bu algılayıcıların alt bileşenleri bilinmemektedir (Salesse ve Gervais 2012); dil yapısının uzun doymamış zincirlere sahip yağlı asitler için algılayıcılara sahip olduğu yakın bir tarihte (on yıldan daha az) keşfedilmiştir (Laugerette vd. 2006). Bu durum, önemli farklı buluşların hala yapılabileceği anlamına gelmektedir! Bu arada, sitrik, malik, tartarik, asetik, askorbik veya laktik asitler veya glukoz, fruktoz veya laktoz gibi sakaritlerin yanı sıra geleneksel sakaroz kullanılabilir, ancak sonucu değerlendirebilecek deneysel testlere ihtiyaç duyulmaktadır.

Trigeminal etkiler için, öjenol (karanfilden), mentol (sadece enantiomerlerinden biri), kapsaisin (biberden), piperin (biberden), etanol, sodyum bikarbonat ve diğerler bileşikler gibi trigeminal etkiler için bazı taze veya keskin bileşikler bilinmektedir. Ancak algılayıcılar hakkındaki bilgi birikimimiz yeni ürünlerin keşfedilmesine yarar sağlayabilir.

Yapısal açıdan, teknolojik çalışmalar yapılabilir, çünkü kolloidal ürünlerin üretimi için daha fazla çalışma yapılması gerekmektedir. Basit emilsiyonlar yapmak bazen zor bir işlemdir, fakat daha genel anlamda, surimi ve benzeri sistemler olmasına rağmen, formüle edilmiş ürünlerin dokular haline getirilmesinin tam anlamıla çözülmüş bir konu olmadığı bilinmektedir. Yeşil bir elmanın kıvamını ayarlayabilmekte kim başaralı olabilir ki? Ya da bir armuttun? Ya da bir çileğin? Benzer sorun sadece laboratuvar prototipleri için değil, seri üretim yapabilmek içinde geçerlidir.

Genel anlamda yapılması gereken birçok şey bulunmaktadır. NbN mutfak uygulamalarının pek çok yönü bilim ve teknoloji açısından incelenmeye devam edilmektedir. Bu paragrafi önemli bir yorum ile tamamlayalım: Hali hazır- 
da var olan gida maddelerini üretmek ilgi çekici olmazdi. Sintizayzırların bir piyanonun veya bir kemanın seslerini yeniden üretebildiği gibi, $\mathrm{NbN}$ mutfakta şaraplar, havuçlar veya etleri yeniden oluşturabilir. . Fakat niçin oluştursun ki? Uzun süreler boyunca seyahat etmek zorunda kalan astronotların haricinde, muhtemelen hâlihazırda zaten var olanı yeniden üretmek hiç kimse için herhangi bir değer ifade etmeyecektir. Hatta geleneksel gıda katkı maddeleri kullanılarak daha önce üretilmemiş lezzetleri veya yiyecekleri araştırmak çok daha heyecan verici olabilir (This 2003).

Basit bir hesaplama, keşfedilebilecek olanın s1nırsızlığını gösterebilmektedir. Geleneksel gıda katkı maddesi sayısının 1.000 ve geleneksel bir tarifin yaklaşık 10 katkı maddesini kullanıldığ varsayılırsa, üretilebilecek yiyeceklerin olasılıklarının sayısı 1.000 üstü 10'a çıkacaktır (ya da 1030). Bununla birlikte, bileşenlerde bulunan bileşiklerin sayısının yaklaşık 1,000 olduğunu ve $\mathrm{NbN}$ mutfak uygulamalarında kullanılacak bileşiklerin sayısının 100 seviyesinde olduğu varsayılırsa olasılık sayısı yaklaşık 103000 olacaktır. Ayrıca bu hesaplamalarda, her bir bileşiğin konsantrasyonunun uyarlanabileceği de hesaba katılmamıştır. Bu, yepyeni bir lezzet kıtasının keşfedilmesi anlamina gelmektedir.

\section{BESLENME ILE ÍLGILI KONULAR}

Burada şunu söyleyerek başlamalıyız ki, geleneksel yiyecekler sağlıklı olmayı garanti etmemektedir. Dünyanın obezite hastalığı ile karşı karşıya olduğu unutulmamalıdır (International Obesity TaskForce 2003)! Elbette bazıları modern beslenme alışkanlıklarını eleştirecektir, ancak yeni g1da çerçevesinin modern yaşam anlayışı içerisinde insanlar için uygun olmadığını gözlemlemek daha uygun olacaktır. Nitekim insanoğlu birçok kez bolluk ve kıtlık ile karşı karşıya kalmıştır (Elsis 2002) ve genetik beslenme bilimi günümüzde insan vücudunun bu koşullar ile yüz yüze kalabileceği mekanizmaları ortaya koymaktadır (Meugnier vd. 2007). Örneğin çok fazla yiyecek tüketmek sandığımız gibi boşaltım sisteminin daha iyi çalışmasına neden olmaz, bunun aksine vücutta yağ depolanmasını artıracaktır.
Şimdi neden $\mathrm{NbN}$ mutfağının beslenme açısından ilginç olabileceğini göz önünde bulunduralım. Bu soru, 'light ürünler' yapmakla ilgili bir durumdur. Tatlandırıcıların kullanımı aşırı tüketime neden oluyor mu? Bu konuyla ilgili önceki çalışmalar, $\mathrm{NbN}$ mutfağının uzun vadeli etkilerinin incelenmesine neden olmaktadır.

Açıkça görülmektedir ki, beslenme bilimi hala vitamin, oligoelement ve küçük besin maddelerinin kullanımı ile ilgili cevaplanması gereken birçok soruya sahiptir. Yiyeceklerdeki bu elementler ile ilgili her şeyi bildiğimizi düşünmek yanlış olurdu. Örneğin, Avrupa'da E vitamini takviyesi ile ilgili yapılan bir araştırma, sigara içen ve $E$ vitamini (belirli antioksidan özelliklere sahip bir grup hidrofobik bileşik) takviyesini almayı kabul eden katılımcı grubunda daha yüksek bir ölüm riski oranı izlenmesi nedeniyle durdurulmak zorunda kalınmıştır (Yusuf vd. 2000).

\section{TOKSіKоLоJi}

$\mathrm{NbN}$ mutfak uygulaması toksikoloji meselesini de göz önünde bulundurmamız gerektiğini bizlere düşündürmektedir. Özellikle, düşük dozda bileşiklerin uzun süre tüketilmesinin sonuçlarının neler olabileceği ile ilgili daha fazla araştırma yapılmasına ihtiyaç duyulmaktadır. Bu alanda sitokrom P450 polimorfizminin ya da son zamanlarda yosunlar tüketildiğinde, yosunların barındırdığı bakteriler ile insan bağırsağındaki bakteriler arasındaki gen transferleri gibi faydalı etkilerin sıkça bulunduğu bilimsel çalışmaların potansiyeli çok fazladır (Hehemann vd. 2008).

Garip bir durumda estragole (kimyasal bileşenler) ile ilgilidir; tarhun otu ve fesleğenin uçucu yağlarının toplam bileşiminin \%50'sinden fazlasını oluşturan estragole (kimyasal bileşenler) 'dır (Nesslany vd.2010). Bu bileşiğin hidroksil türevi toksik görünmektedir (Anthony vd. 1987), ancak çoğunlukla bu tür bitkileri tüketen popülasyonlarda karaciğer kanseri vakası görülmemesinin nedeni anlaşılamamıştır (Nesslany vd. 2010).

Toksikolojik bakış açısıyla, NbN mutfak, hayvan ve bitki dokularının hiçbir zaman tadının bilinmediği geleneksel mutfaklardan farklı olmayacaktır. Modern gidaların geleneksel yiyeceklere göre daha fazla üzerinde çalışıldığı modern 
beslenme alışkanlığının bir paradoksudur. Bazı geleneksel gıdaları günümüzde sunulsaydı, tüketimlerine imkân verilmeyebilirdi.

$\mathrm{NbN}$ mutfağı, toksik bileşikleri kullanmayarak toksisiteden uzak durabilir. Örneğin, benzopirini gıdalardan uzaklaştırabilir veya hindistancevizi kökenli toksik miristik zehirlenmeyi (6-allil-4metoksi-1,3-benzodioksole) estragole; patateslerden ve domateslerden elde edilen glikoalkaloidleri; lahana glukozinolatlarıni; bitki dokularından bazı fenolikleri ve benzeri maddeleri önleyebilir (Bruneton 2001). Ancak, insanlar, mangalda pişirilen ve içeriği benzopirin dolu yiyecekleri tüketmeye devam etmek isteyerek dilediklerini yapmakta yine de özgürdürler!

Gıda ürünlerinin düzenlenmesi ile ilgili konular sıvı azot, ultrasonik sondalar ve döner buharlaştırıcıların 'moleküler aşçılara' satılması konusuyla benzer olacaktır. Uygulamalardaki bu gelişmeler gaz ve elektriğin evlerde kullanılmasına benzer şekilde yeni düzenlemelere ihtiyaç duyulmasına neden olacaktır. NbN mutfak ürünlerinin geleneksel mutfaktaki bıçak veya gazdan daha tehlikeli olmaları nedeniyle değil de, mutfak dünyasındaki her toplumda belirli oranda sivi bir azotu kapalı bir şişeye koyan Alman bir adam gibi dikkatsiz insanların bulunması nedeniyle kesinlikle bazı kazaların olacağını kabul edebiliriz (The Tlegraphy 2009)!

Öncelikle, bu tartışmadan elde etmeyi önerdiğim olgu, bilimsel ve teknolojik konuların birbirinden çok farklı olarak düşünülmesi gerektiğidir. Bu bileşiklerin vücut üzerindeki etkisini öğrenmenin zamanı geldi.

\section{SANAT, ÖNCELIKLI!}

Sanat karmaşık bir kavramdır, ancak basitleştirebilmek adına, mutfak sanatının da resim, müzik, heykel, edebiyat ve diğer sanatlardaki gibi duygular yaratmaya yönelik olduğunu iddia edebiliriz (This ve Gagnaire 2008). Sanatçlların eserlerine yeni fikirler getirmeyi hiç bırakmadıkları gibi gurmeler de yeni tatlar ve yeni hislerin peşinden gitmeyi terk etmeyeceklerdir. Bu bağlamda, $\mathrm{NbN}$ mutfağı yeni olanaklar yaratabileceği için gurmeleri memnun edebilir.
$\mathrm{NbN}$ mutfağ1 zor mudur? Elbette ki aşçılar, kendilerine sunulan malzemelerin listesine daha fazla aşina olmak zorunda kalacaklardır, ancak yeni tarifler tanıtılmaya devam ettikçe bu iş giderek daha da kolaylaşacaktır. Her $\mathrm{NbN}$ mutfak etkinliği düzenlediğimizde, aşçıların bilmediği bileşikleri kullanması gerekmekteydi, ancak zamanla bu ürünleri yeni lezzetler ile dikkate değer yiyecekler yapmak için kullanmayı öğrenmişlerdir. Elbette, bu yemeklerin lezzetini tarif etmek pek mümkün değildir. Göremediğiniz birine mavi rengi nasıl tanımlayabilirsiniz? Ayrıca yemeklere isim vermekte zor bir işlemdi, parfüm sektörü ( ${ }^{\circ} 5$, Channel, Shalimar, vb.) bu sorununun üstesinden gelmemize yardımcı olmuştur.

Geleneksel güveç, cassoulet ya da choucroute'u kaybetmekten korkan bireylere modern sanatın eski sanatın yerini alamadığını aksine ona daha fazla özgürlük ve daha fazla seçenek kazand1rarak yenilik kattığının belirtilmesi gerekmektedir. Debussy, Mozart veya Bach'ı yok etmemiştir; Picasso ve Buffet bizlerin Rembrandt'a ya da Brueghel'e hayran olmasını engellememiştir. Ya da moleküler mutfak, yenilikçi mutfak veya geleneksel mutfak anlayışlarını yok etmemiştir. $\mathrm{NbN}$ mutfak gastronomi dünyasında sadece sanatsal bir katkıdır.

\section{EKONOMI}

NbN mutfağın maliyeti ne düzeyde olacaktır? $\mathrm{NbN}$ mutfağın maliyeti şu anki mutfak uygulamalarından daha fazla mı olacaktır? NbN mutfağının başarısı için bir sonraki ek bir maliyet artışının belki de kilit unsur olabileceği düşünüldüğünde, enerji konusun dikkate alınması gerektiği açıkça görülecektir. Günümüzde, şefler herhangi bir sos hazırlarken şarap veya bulyonu "yoğunlaştırmak" amacıyla suyu buharlaştırmaktadırlar (Ancak buharlaştırma nedeniyle birçok koku bileşeni de kaybolmaktadır). Profesyonel bir aşç1nın yaptığı gibi, bir yoğunlaştırma işleminin üçte iki oranında olması gerektiğini varsayarsak, basit bir hesaplama, tüketilen enerjinin $0,417 \mathrm{kWh}$ olduğunu ve bununda sos başına 0,05 Euro gibi bir miktara tekabül eden bir rakama denk geldiğini göstermektedir (This 2012). 
Enerji maliyeti sorunu, etlerin $200^{\circ} C^{\prime}$ den daha yüksek bir sıcaklıkta isıtıldığı geleneksel mutfaklarda dikkate alınmamaktadır; ancak $\mathrm{NbN}$ mutfak yöntemiyle, kitlesel halde üretilmiş bileşikler çok daha düşük bir maliyetle üretilebileceği söylenebilir.

Buna ek olarak, aşçılar tarafından kullanılan tüm bileşiklerin sentezlenmesi gerekmemektedir. Günümüzde klorofiller gibi bu bileşikler, bitki materyallerinin özünden elde edilebilmektedir. Kimyagerler, B12 vitamini sentezlemek için yüzlerce kimyager yılının gerekli olduğunun farkındadırlar (Woodward 1973), bu nedenle etkili bir kimyasal yöntemin yokluğunda tarım ve bitkilerin özütünü elde etmek için kullanılan ekstraksiyon uygulamaları en etkili yöntemlerdir. $\mathrm{NbN}$ mutfak, sentezlenmiş veya özü çıkarılmış ürünleri, nereden geldiklerine bakılmaksızın kullanabilir.

\section{SIYASAL VE TOPLUMSAL KONULAR}

$\mathrm{NbN}$ mutfağının ilk uygulamaları, 'kimyasallar' yiyebileceğimiz gibi deli bir düşünce nedeniyle kaçınılmaz olarak korku yaratmıştır. Tam bu noktada, örneğin konu genetiği değiştirilmiş organizmalara gelince, politik fikirler hâlihazırda üzerinde tartışılan başka konular ile birbirine karışmaktadır. NbN mutfak yalnızca iyi anlatıldığında veya açlık sıkıntısı çeken ülke vatandaşlarının bile ret ettiği bir zamanda Augustin Parmentier'in Fransa kralına patates yemeği kabul ettirdiği gibi bir "otorite argümanı" kullanıldığı takdirde başarılı olabilir (SanterreBaillet 2010). Ancak, genetiği değiştirilmiş organizmalarda olduğu gibi, $\mathrm{NbN}$ mutfağının insanlık için dezavantajlı olacağından korkmalı mıyı? Olası düşük olsada tüm gidalar, NbN mutfak kullanılarak yapıldığında çiftçiler nasıl geçimlerini sağlayabilirler? Bu sorular kimyagerlerin cevaplayabileceğinden çok daha fazlasını içermektedir, ancak bu konular şu hususu gündeme getirmektedir: İnsanların üzüm satmak yerine, şarap üreterek para kazanmalarına benzer şekilde; çiftçiler de bugün hammadde satmak yerine, bitkilerden damitılarak oluşturulan bileşikler üreterek daha fazla kar elde edebilirler.

Son olarak, $\mathrm{NbN}$ mutfağının değerini takdir ederken, insanlığın bir enerji kriziyle karşı kar- şıya olduğunu belirtmek de gerekmektedir. Geleneksel mutfağın sürdürülebilir oluşunun kesin olmadığ 1 (ki değil!) bir ortamda (Bruneton 2001); yeni usuller her zaman eskisine galip gelmektedir. Süt ve buğday ürünleri için tarım ve çiftçilik ürünlerinin bileşiklerinden ayrıştırılması işlemi, hali hazırda kullanılan normal bir işlemdir (Lorient ve Linden 1994). Neden havuç ve elmalar içinde benzer işlemler yapılmasın ki? Günümüzde NBN mutfağına yönelik yapılan eleştiriler yarım yüzyıl önce elektronik müziğe karşı yapılan eleştiriler ile benzerlik göstermektedir; ancak radyoda bugün ne tarz bir müziğin çaldığının farkında mısınız? Diğer bir deyişle, şuanda Varèse ve diğer zamane müzisyenlerinin elektronik müzik üzerinde çalışma yaptıkları 1947'deki müzik endüstrisinin içinde bulunduğu duruma benzer bir durumun içerisindeyiz (This 2012).

\section{KAYNAKÇA}

Anthony, A., Caldwell, J., Hutt, AJ. ve Smith, RL. (1987). Metabolism of Estragole in Rat And Mouse And Influen10 To Contain Toxic, Addictive, Psychotropic Or Other Substances Of Concern, EFSA Journal, 7 (9):281.

Escudier, JL, Bes, M, Mikolajczak, M, Bouissou, D. ve Samson, A. (12 Mart 2010). The Future Of The Wine Sector, http://www.liendelavigne.org/HOME/ANG/DefaultANG.htm, Erişim tarihi: 01 Ocak 2013.

Finedininglovers. (14 Arallk 2011). Daniel Facen, The Scientific Chef. http://www.finedininglovers.com/stories/ molecular-cuisine-science-kitchen, Erișim tarihi: 01 Ocak 2013.

Gelatin-Gmia. (01 Ocak 2013). Gelatin Manufacturers Institute of America homepage. http://www. gelatin-gmia.com, Erişim tarihi: 01 Ocak 2013.

Hehemann, H., Correc, G., Barbeyron, T., Helbert, W., Czjzek, M. ve Michel, G. (2008). Transfer of Carbohydrate-Active Enzymes From Marine Bacteria To Japanese Gut Microbiota, Nature, 464: 908-912.

Horizon-2020. (01.01.2003) . Introduction of Innovative Technologies in Modern Gastronomy for Modernization of Cooking, http://www.ist-world.org/ProjectDetails.aspx? Project Id=2df59ae3a55d4c14a67d63e25d73748d, Erişim tarihi: 01 Ocak 2013.

Hotellerie-Restauration. (09 Şubat 2011). Centre de Resources Nationales Hôtellerie Restauration: Ça vient d'avoirlieu!, http://www.hotellerie-restauration.ac versailles.fr/ spip.php?article1615, Erişim tarihi: 01 Ocak 2013.

International Obesity TaskForce. (2003). Waiting for a green light for health? IOTF Position Paper. Londra: IOTF.

Ircam. (01 Haziran 2010). Institute de Recherche et Coordination Acoustique/Musique, http://www.ircam.fr/recherche. html, Erişim tarihi: 01 Ocak 2013. 
Kurti, N. (1969). Friday Evening Discourse At The Royal Institution: The Physicist in The Kitchen. Proceedings of the Royal Institution, 42/199: 451-467.

L'Hotellerie-Restauration. (06 Mayıs 2009). Menu Constructivisme Culinaire Pour Pierre Gagnaire, http://www. lhotellerie-restauration.fr/journal/restauration/2009-05/ Menuconstructivisme-culinaire-pour-Pierre-Gagnaire. htm, Erişim tarihi: 01 Ocak 2013.

Laugerette, F., Passilly-Degrace, P., Patris, B., Niot, I., Montmayeur, JP. ve Besnard, P.(2006). [CD36, a major landmark on the trail of the taste of fat], Med Sci, 4 (22): 357-359.

Lorient, D. ve Linden, G. (1994). Biochimie Agro-industrielle. Paris: Masson.

Mark, R. E. (09 Şubat 2002). Starvation.net Homepage. The Three Top Sins Of The Universe, http://www.starvation.net/, Erişim tarihi: 01 Ocak 2013.

Meugnier, E., Bossu, C., Oliel, M., Jeanne, S., Michaut, A., Sothier, S., Brozek, J., Rome, S., Laville, M. ve Vidal, H. (2007). Changes in Gene Expression in Skeletal Muscle in Response To Fat Overfeeding in Lean Men, Obesity, 15 (11):2 583-2594.

Moleculargastronomynetwork. (01.01.2013). "Molecular gastronomy Network Homepage", That Some Merchants are doing, Using The Name Of A Trendy Scientific Discipline For Their Business, http://www. moleculargastronomynetwork.com/recipes.html, Erişim tarihi: 01 Ocak 2013.

Nesslany, F., Parent-Massin, D. ve Marzin, D. (2010). Risk Assessment Of Consumption Of Methylchavicol And Tarragon: The Genotoxic Potential in Vivo And in Vitro, Mutat Res, 696 (1): 1-9.

Ohshima, H., Friesen, M., Malaveille, C., Brouet, I., Hautefeuille, A. ve Bartsch H. (1989). Formation of Direct-Acting Genotoxic Substances in Nitrosated Smoked Fish And Meat Products: Identification of Simple Phenolic Precursors And Phenyldiazonium Ions As Reactive Products, Food Chem Toxicol, 27 (3):193-203.

Pasteur, L. (1924). Note sur l'enseignement Professionnel, Adressée à Victor Duruy, 10 nov. 1863. In OEuvres Completes. Paris: Masson, 187. t.7.

Perram, CM., Nicolau, C. ve Perram, JW. (1977). Interparticle Forces İn Multiphase Colloid Systems: The Resurrection Of Coagulated Sauce Béarnaise, Nature, 270: 572.

Pierre-Gagnaire. (01 Mayıs 2012). Dictons, Davoir et Gourmandise, http://www.pierregagnaire. com/\#/pg/pierre_et_herve, Erişim tarihi: 01 Ocak 2013.

Pliner, P. ve Hobden, K. (1992). Development of a scale To Measure The Trait Of Food Neophobia in Humans, Appetite, 19 (2): 105-120.

Rietjens, M., Martena, MJ., Boersma, MG., Alink, GM. ve Spiegelenberg, W.(2005). Molecular Mechanisms Of Toxicity Of Important Food-Borne Phytotoxins, Mol Nutr Food Res, 49 (2): 131-158.

Roberfroid, M., Coxam, V. ve Delzenne, N. (2007). Aliments Fonctionnels. Paris: Lavoisier Tec et Doc.

Salesse, R. ve Gervais, R. (2012). Odorat et goût. Paris: Quae; 439-449.

SanterreBaillet. (01 Ocak 2010). Histoire de Montdidier, http:// santerre.baillet.org/communes/montdidier/ v2b/ v2b4c02b54.php, Erişim tarihi: 6 Temmuz 2012.
The Telegraphy. (14 Temmuz 2009). German Heston Blumenthal Blows Off Both Hands in Liquid Nitrogen Kitchen Accident, http://www.telegraph.co.uk/news/ worldnews/europe/germany/5821433/German-HestonBlumenthalblows-off-both-hands-in-liquid-nitrogenkitchen-accident.html, Erişim tarihi: 01 Ocak 2013.

This, H. (1995). La Gastronomie Moléculaire et Physique (Basılmamış Doktora Tezi). Paris: VI University.

This, H. (1997): Une Petite Histoire de la Gastronomie Moléculaire. Papilles (Roanne), 13: 5-14. Geoffroy Le Cadet M: Mémoires de l'Académie Royale, Histoire de l'Académie Royale des Sciences, Année MDCCXXX, 312. Amsterdam: Pierre Mortier; 1733.

This, H. (1998). La Gastronomie Moléculaire et l'avancement de l'art Culinaire. Sciences, Publication de l'Association Française pour l'Avancement des Sciences (AFAS), 98 (7): 3.

This, H. (1999). Froid, Magnétisme et Cuisine: Nicholas Kurti (1908-1998, Membre d'honneur de la SFP), Bulletin de la Société fFrançaise de Pphysique, 119 (5): 24-25.

This, H. (1999). La Gastronomie Moléculaire et ses Applications: Keynote lecture of the Doctoriales de l'Université de Haute Alsace.

This, H. (2003). La Gastronomie Moléculaire, Sciences des Aliments, 23 (2): 187-198.

This, H. (2003). La Gastronomie Moléculaire, Sciences des Aliments, 23 (2): 187-198.

This, H. (2004). Molecular Gastronomy: A Scientific Look To Cooking. İçinde: S. Halldor (Editör) In Life Sciences in Transition, Special Issue of the Journal of Molecular Biology. Cambridge: Elsevier Science Ltd; 150.

This, H. (2005). Modelling dishes And Exploring Culinary 'Precisions': The Two Issues of Molecular Gastronomy, 93 (4): 139-146.

This, H. (2007). Formal Descriptions For Formulation, Int J Pharmaceut, 344 (1-2): 4-8.

This, H. (2008). Descriptions Formelles, Pour Penser et Pour la Formulation, L'Actualité Chimique, 322 (8): 11-14.

This, H. (2009). Cours de Gastronomie Moléculaire $N^{\circ} 1$ : Science, Technologie, Technique (Culinaires): Quelles Relations?, Paris: Quae/Belin.

This, H. (2010). Cours de Gastronomie Moléculaire N²: les Précisions Culinaires. Paris: Belin Litterature et Revues.

This, H. (2011): Molecular Gastronomy in France, Journal of Culinary Science \& Technology, 9 (3): 140.

This, H. (2012). Apprenons Enfin à Cuisiner de la Couleur! In La Couleur des Aliments, de la Théorie à la Pratique. Jacquot M.: M, Fagot P. ve Voilley A. (Editörler) Paris: Tec et Doc Lavoisier: 431-443.

This, H. (2012). La Cuisine Note à Note en 12 Questions Souriantes. Paris: Belin.

This, H. (2012). Solutions are Solutions, And Gels Are Almost Solutions, Pure Appl Chem., ASAP article. http://dx.doi. org/10.1351/PAC-CON-12, Erişim Tarihi: 09 Ekim 2012.

This, H. ve Gagnaire, P. (2008). Cooking: The Quintenssential Art. Los Angeles: University of California Press.

This, H. ve Kurti, N. (1994): Physics and Chemistry in the Kitchen, Sci Am, 270 (4): 44-50.

This, H. ve Kurti, N. (1995). The Cooking Chemist, The Chemical Intelligencer, 1: 65. 
This, H., Salesse, R. ve Gervais, R. (2012). Gastronomie Moléculaire et Olfaction. In Odorat et Goût. Paris: Quae: 439-449.

Trésor de la Langue Française. (2006). Electronic Version, http://atilf.atilf.fr/tlf. Htm, erişim tarihi: 01 Ekim 2006.

Weaver, WT. (1970). Molecular Biology, Origins Of The Term, Science, 170: 591-592.

Woodward, RB. (1973). The Total Synthesis Of Vitamin B12, Pure Appl Chem, 33 (1): 145-178.
Yusuf, S., Dagenais, G., Pogue, J., Bosch, J. ve Sleight, P. (2000). Vitamin E Supplementation And Cardiovascular Events in High-Risk Patients, The Heart Outcomes Prevention Evaluation Study Investigators, New Eng J Med, 342 (3):154-160

Zawistowski, J, Biliarderis, CG, Eskin NAM. (1991). Polyphenoloxidase. İçinde: DS Robinson, NAM Eskin (Editörler). In Oxidative Enzymes in Food (ss. 217-273). Londra: Elsevier Applied Science.

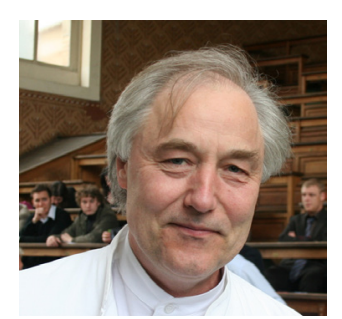

Herve THis

Birçok mutfak akademisine ve araştırma enstitüsüne üyeliği bulunan yazar, Académie d'Agriculture de France' da Gıda Bölümü Başkanıdır. Aynı zamanda Moleküler Gastronomi disiplinin kurucudur ve halen Moleküler Gastronomi üzerinde çalışmalarını aktif bir şekil devam ettirmekっtedir. Çalışmaları önde gelen kimya ve gastronomi dergilerinde yayımlanmıștır. Ayrıca birçok dile çevirisi de yapılış̧ olan toplamda 18 adet kitap yazmıştır. Halen Ordre des Palmes Académiques,'da görev yapmaktadır.

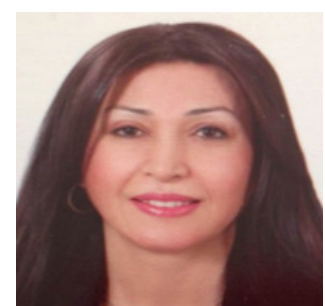

\section{Sehnaz DEMIRKOL}

1988 yılında İstanbul Üniversitesi, Turizm İșletmeciliği ABD'de yüksek lisansını ve 1991 yılında doktora eğitimini tamamlamıştır. Yazar, 1996 yılında Sakarya Üniversitesi, îktisadi İdari Bilimler Fakültesi, Turizm İșletmeciliği Bölümü'ne öğretim üyesi olarak atanmıştır. 1999-2000 yılları arasında İngiltere'de Liverpool University'de misafir öğretim üyesi olarak bulunmuştur. Yazar, 2006 yılından beri İstanbul Üniversitesi, İktisat Fakültesi, Turizm İşletmeciliği Anabilim Dalı'nda görevine devam etmektedir.

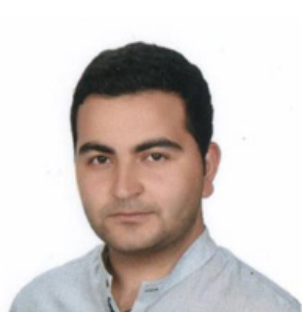

\section{ibrahim çifçi}

2012 yılında Sakarya Üniversitesi, İktisadi İdari Bilimler Fakültesi, Turizm İșletmeciliği Bölümünde turizm eğitimini tamamlamıştır. 2014 yılında İstanbul Üniversitesi, Turizm İșletmeciliği ABD'de yüksek lisansını eğitimini tamamlayarak aynı yıl İstanbul Üniversitesi, İktisat Fakültesi, Turizm İşletmeciliği Bölümü'ne araștırma görevlisi olarak atanmıștır. Yazar, 2015 yııında İstanbul Üniversitesi, Turizm İşletmeciliği Anabilim Dalı'nda doktora eğitimine başlamış ve halen aynı kurumda doktora eğitimine devam etmektedir. 